Altunbay, M. (2017). Türkçe öğretmeni adaylarının dünya edebiyatını takip etme düzeyleri. Ana Dili Eğitimi Dergisi, 5(3), 433-449.

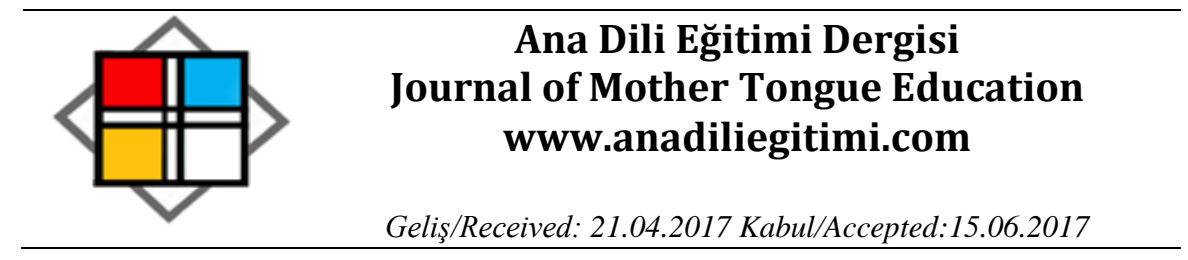

\title{
Türkçe Öğretmeni Adaylarının Dünya Edebiyatını Takip Etme Düzeyleri
}

\author{
Müzeyyen ALTUNBAY**
}

\section{Öz}

Bilindiği gibi edebiyat onu oluşturan toplumun bir ürünü olup aynı zamanda toplumu etkileme gücüne de sahiptir. Bu yönüyle millî değerleri yansııır; ancak millî edebiyattan dünya edebiyat kavramına gelince, günümüzde hâlen ihtilaflı görüşler bulunmaktadır. Bu nedenle kesin olarak sınırı çizilemeyen dünya edebiyatı kavramının bir çerçeveye oturtulması kolay değildir. Genel olarak pek çok toplumun edebiyatının birleşimi dünya edebiyatı kapsamında ele alınmaktadır. Söz gelimi İtalyan Edebiyatından Lübnan Edebiyatına, Fransız Edebiyatından İrlanda Edebiyatına kadar birçok toplumun edebiyatı millî edebiyat özelliği gösterse de bu edebiyatların tamamı, aynı zamanda dünya edebiyatı kapsamında değerlendirilmektedir. Bu durum, eğitimde -özellikle dil öğretiminde- metin kullanımında zengin bir malzeme olanağı sunar. Bununla birlikte bu malzemenin kullanılabilmesi ve bakış açısı zenginliğinin kazanılabilmesi için dünya edebiyatının takip edilebilmesi gerekmektedir. Bu çalışmada Türkçe öğretmeni adaylarının dünya edebiyatını takip etme düzeylerinin tespit edilmesi amaçlanmıştır. Çalışmada tarama modeli kullanıımıştır. Katııımcıların dünya edebiyatını ağılıklı olarak çeviri eserler aracılı̆ı ile takip ettikleri, en son okunan ile sürekli takip edilen eserler arasında Amerikan edebiyatının ilk sıralarda yer aldığı, edebiyat çevirmeni bilme/tanıma ile uluslararası edebiyat ödülü bilme konularında Türkçe öğretmeni adaylarının yetersiz oldukları, dünya edebiyatının en fazla romanlar araclığı ile takip edildiği, bu sonucu sinema ile takip etme seçeneğinin aldığı ulaşılan sonuçlardan bazılarıdır.

Anahtar Kelimeler: dünya edebiyatı, Türkçe eğitimi, dil eğitimi, metin kullanımı, çeviri eser.

\section{Turkish Teacher Candidates' Levels of Following the World Literature}

\begin{abstract}
As known, literature is a product of the society that makes it and, at the same time, it has the power to influence the society. In this way, it reflects national values; however, when it comes to the concept of the world literature, there are views that are still controversial today. Hence, it is not easy to fit the concept of world literature, the boundaries of which cannot be established with precision, into a framework. In general, the combination of the literature of many societies is considered as world literature. Although many literatures from the Italian to the Lebanese literature, from the French to the Irish Literature show national literary features, all of these literatures are also considered within the context of world literature. This case provides rich material opportunities for text use in education, especially in language teaching. In addition, in order to use this material and gain a richer perspective, it is necessary to follow world literature. In this study, the aim was to determine the levels of Turkish teacher candidates' following of world literature. Survey model was used in the study and the data obtained were presented in the Findings section. The findings showed that the participants followed world literature predominantly through translated works, the American literature was in the first place among the most recent and continually pursued works, Turkish teacher candidates were inadequate in terms of the knowing literary work translators and international literary awards, and that world literature was followed mostly via novels and that watching movies followed novels.
\end{abstract}

Keywords: World literature, Turkish education, language education, text use, translated work.

\footnotetext{
* Yrd. Doç. Dr, Giresun Üniversitesi Eğitim Fakültesi Sosyal Bilimler ve Türkçe Eğitimi Bölümü Türkçe Eğitimi Ana Bilim Dalı. Giresun. e-posta: altun.bay@hotmail.com
} 


\section{Giriş}

Tarihi belgeler, toplumsal belleğin dikili taşlarıdır. En az tarihi belgeler kadar edebî metinler de toplumsal belleğin yansıması ve ürünüdür. Bu sebepledir ki sosyolojik çalışmaların ayrılmaz bir parçasıdır edebiyat. "Bir kültürün anlaşıımasında kuşkusuz edebiyatın özel bir yeri var" (Gürbilek, 2004: 13) diyen Gürbilek (2004) aynı noktaya temas eder. 21. yüzyılda giderek artan karşılaştırmalı edebiyat çalışmaları da toplumlararası etkileşimin yarattığı ortaklıklar ve gün yüzüne çıkardığı farklılıklara değinerek, edebî metinlerle toplum yapısı arasındaki bağa vurgu yapar.

20. yüzyılda Welttliterature kavramıyla "dünya edebiyatı" terimini ortaya atan Goethe, yerelden evrensele uzanan bir edebiyattan bahseder. Goethe, "Şimdilerde ulusal edebiyat sözü pek fazla bir şey ifade etmiyor, dünya edebiyatı çağı yakındır ve bu çağın gelişini hızlandırmak için de herkes kendine düşeni yapmalı" (Damrosch, 2013: 1) diyerek millî edebiyattan ziyade dünya edebiyatının önem kazanacağını belirtir. Tekşan’a (2011) göre ise Goethe bu tanımında yanılmaktadır. 21. yüzyılda artan teknolojiye ve işbirliğine rağmen, yerel değerler korunmakta, hatta millî edebiyatlar daha da yaygınlaşmaktadır. Tekşan (2011), "iletişim araçlarının çok hızı gelişmiş olması ve çeşitlenmesi dünya edebiyatının oluşmasında çok etkili olması gerekirken süreç bu noktada tersine işlemiş gibi gözükmektedir. Gelişen ve hızlanan iletişim araçları dünya edebiyatı yaratamadığı gibi ulusal edebiyatların daha çok gelişmesine fırsat yaratmıştır" (Tekşan, 2011: 12) diyerek Goethe'nin düşüncesinin aksini savunur. Aynı zamanda son dönemde yazılmış birçok eserde yerel değerlerin korunup savunulduğuna dikkat çekerek bu durumun millî edebiyatların değil sonunu getirmek, aksine onları daha da artıracağını ve yaygınlaştıracağını ifade eder. "Günümüzde Aborjinlerin hayatından esinlenerek yazılmış bir romanın, Bir Çift Yürek, dünyanın en önde gelen eserlerinden biri olması üzerinde durulacak bir olgudur. Günümüz insanı dünyanın değişik yerlerindeki çeşitli yaşam biçimlerini öğrenmeye ve onların güzelliklerini keşfetmeye yönelmektedir. Modernizmin ürünü olarak ortaya çıkan birbirinin aynı yaşam biçimi giderek yerini farklı milletlerin, farklı bölgelerin ve farklı yaşam biçimlerine bırakmaktadır" (Tekşan, 2011: 13) diyen Tekşan, bu sayede dolaylı olarak yerel değerlerin daha çok korunduğuna dikkat çeker.

Günümüz dünya edebiyatı anlayışı Goethe'ninkinden kısmen farklı ve daha geniş kapsamlı olarak ele alınmakta, farklı toplumların kültür ürünü olan edebiyatlarının toplamı olarak kabul edilmektedir. Bununla birlikte bir eserin dünya edebiyatı kapsamında kabul edilip edilmemesinin kesin sınırları belli değildir. Damroch, bu nedenle edebiyatı genel edebiyat, kültürel edebiyat ve sanatsal edebiyat olarak üçe ayırır. Sanat yapıtlarının nasıl okunması gerektiği yönündeki görüşlerini ise şu şekilde sıralar: "Belli bir edebiyat geleneği içinde, yazarlar ve okuyucular, farklı türden yapıtların nasıl okunacağına dair bir beklenti zemini oluştururlar ve tecrübeli okuyucular, eserin ne şekilde anlaşılacağına dair müşterek bir kanaatle metne yaklaşabilirler" (Damroch, 2016: 10-11) diyerek 
Türkçe Öğretmeni Adaylarının Dünya Edebiyatını Takip Etme Düzeyleri

edebî metinlerin okunmasında okuyucu-yazar ilişkisi üzerinde durur. Bu ise alımlama estetiği kuramını akla getirir. "Bu kuram, doğrudan doğruya okuru merkeze alır. Okurun bilgisi, birikimi ve donanımı eserin algılanmasında, anlamlandırılmasında birincil rol oynar. Yazarın bilerek veya bilmeyerek bıraktığı anlam boşluklarını okuyucu tamamlar. Böylelikle metnin içine dâhil edilmiş olur" (Kolcu, 2015: 115).

Dünya edebiyatını okumak kadar takip etmek de süreklilik ister, çünkü insan bir toplumun edebiyatını okurken sadece o toplumun kültürüne değil kendi kültürüne ve tarihine dair de birçok şey öğrenebilir. En azından diğer toplumlar nezdinde nasıl göründüğünü, nasıl algılandığını fark edebilir ki bu duruma en iyi örnek seyahatnamelerdir. Söz gelimi “Ogier Ghislain de Busbecg”in kaleme aldığı "Türkiye'yi Böyle Gördüm" ya da "Joseph Pitton de Tournefort" tarafından yazılan "Tournefort Seyahatnamesi" Türk kültürüne, tarihine, siyasi ve askeri alanlara dair birçok bilginin edinilebildiği eserlerden biridir. Bu nedenle edebiyat insanlığın ortak malı ve ürünüdür denilir. Bu özelliğinden ötürü edebiyata sınır çizmek ve onu bir çerçeveye oturtmaya çalışmak oldukça zordur. Yalçın (2012) “Artık günümüzde dil ve edebiyat çok farklı bir gözle görülüyor. Onlar yaşadığımız bu küçük yuvarlağı anlamlı kılan güzellikler bütünüdür. İnsana ait, insan tarafından geliştirilmiş, insanca işler, duygular ve düşüncelerin elbisesidir" (Yalçın, 2012: 42) diyerek dil ve edebiyatın insanlık için ayrılmaz bir parça oluşuna işaret etmektedir. O hâlde insanlık tarihi kadar eski olan dil ve edebiyatın sınırlandırılması ya da sınıflandırılmasından ziyade, insanlığı daha iyi anlayabilmek için bir araç/bir malzeme olarak kullanılması yerinde olacaktır. Bunun öncelikli yolu ise dünya edebiyatını okumak ve takip etmekten geçer. Çünkü Ülken'e göre medeniyet denilen şey sürekli bir hümanizmadır. "Onu parçalamak veya son halkalarını zincirden koparıp almaya kalkmak mümkün değildir" (Ülken, 2011: 7). Ayrıştırmak yerine bütünleştirmenin, ötekileştirmek yerine kucaklamanın bir yolu da edebiyatı insanlığın ortak ürünü olarak kabul etmekten geçer.

Baytekin (2006) “Modern edebiyatın amacı okurun hayal dünyasını canlandırmak, geliştirmek ve eserin oluşumuna katkıda bulunmaktır" (Baytekin, 2006: 67) diyerek edebiyatın işlevine dikkat çeker. O hâlde dil öğretiminde temel malzeme olarak edebî metinlerin kullanıldığı Türkçe eğitiminde, öğretmen adaylarının edebiyata vâkıf olmaları önem taşır. Özellikle ilköğretimde öğrencilere bakış açısı zenginliğinin kazandırılması, farklı kültürlerin ve yaşam biçimlerinin sunulmasıyla mümkündür. Bunun yolu da sadece Türk edebiyatının değil dünya edebiyatının da okunması ve okutulmasından geçer.

Avcı (2011) tarafından yapılan “Türkçe Ders Kitaplarındaki Dünya Edebiyatı Metinlerinin İçerik Açısından İncelenmesi" konulu lisansüstü çalışmasında, dünya edebiyatı metinlerinin kullanımı hususunda Türkçe Öğretim Programları doğrultusunda hazırlanan ders kitapları arasında farklılıklar 
bulunduğu tespit edilmiştir. Bazı ders kitaplarında dünya edebiyatından metinlere çok yer verildiği, buna karşın bazı ders kitaplarında hiç yer verilmediği tespit edilmiştir.

Çalışkan (2016) tarafından yapılan “ilköğretim 100 Temel Eser İçerisinde Yer Alan Dünya Edebiyatına Ait Eserlerin Değerler Eğitimi Açısından İncelenmesi" konulu çalışmada ise belirtilen liste içerisinde dünya edebiyatı kapsamında toplam otuz eser incelenmiştir. Bu eserler içerisinde sevgi değerinin ve buna bağı olarak en fazla arkadaşlık ve aile değerlerinin öne çıktığı tespit edilmiştir. Böylece dünya edebiyatından örnek metinler aracılığı ile de değer eğitimi verilebileceği görülmüştür.

Uysal tarafindan (2016) yapılan "The Evaluation of World Literature Courses in Turkish Language Teaching Departments Based on Conceptual Field" (Türkçe Eğitimi Programlarındaki Dünya Edebiyatı Dersinin Kavram Alanı Ekseninde Değerlendirilmesi) başlıklı bir diğer araştırmada Türkiye'deki üniversitelerin Türkçe Eğitimi Programlarında verilmekte olan Dünya Edebiyatı dersleri, 1820 'li yıllarda Goethe tarafından kullanılan ve devamında geliştirilen "Dünya Edebiyatı" kavram alanı ekseninde değerlendirilmiştir.

Eğitim-öğretim faaliyetlerinde -özellikle dil eğitimi ve öğretiminde- dünya edebiyatı metinlerinden yararlanabilmek için öğretmen adaylarının dünya edebiyatı ile ne derece ilgili olduklarının tespit edilmesi gerekmektedir. 2017 Türkçe Dersi Öğretim Programında (http://ttkb.meb.gov.tr/www/ogretim-programlari/icerik/72) ders kitabına alınacak metinlerin nitelikleri arasında "Ders kitaplarına alanda yaygın olarak kabul görmüş yazar ve eserlerden edebî değer taşıyan metinler alınmalıdır." ile "Dünya edebiyatından seçilen metinler, doğru ve nitelikli çevirilerden alınmalıdır." ifadeleri yer almaktadır. Yaygın kabul görmüş yazar ve edebî eser ifadeleri daha çok klasik eserler ile ödüllü eser ve yazarları çağrıştırmaktadır. illköğretim okullarına tavsiye niteliğinde olan 100 Temel Eser içinde gösterilen edebî eserlerden dünya edebiyatına ait olanların birçoğunun klasik eserler olması, bu görüşü doğrular niteliktedir. Bu nedenle çalışmada Türkçe öğretmeni adaylarının dünya edebiyatını takip etme düzeylerinin belirlenmesi amaçlanmıştır.

\section{Yöntem}

Bu bölümde çalışmanın önemi, örneklem, verilerin toplanması ve analizi bölümleri yer almaktadır. Bu çalışmada Türkçe öğretmeni adaylarının dünya edebiyatını takip etme düzeylerine yönelik var olan durum, olduğu şekliyle ortaya konmaya çalışıldığından tarama modeli kullanılmıştır.

Araştırma, Türkçe öğretmeni adaylarının dünya edebiyatı kapsamındaki ödüllü eserler ile diğer edebî eserleri, ödül almış yazarları bilme ve uluslararası edebiyat ödüllerini takip etme düzeylerinin tespit edilmesi açısından önem taşır. Çalışmanın bulgu ve sonuçları tespit niteliğinde olup “Türkçe öğretmeni adaylarının edebiyattan yararlanmaları ile metin kullanımı" vb. konularında araştırma yapacaklara katkı sunacağı düşünülmektedir. 


\section{Örneklem grubu}

Bu çalışmada örneklem grubunu 2015-2016 Eğitim-Öğretim yılında Giresun Üniversitesi Eğitim Fakültesi Türkçe Eğitimi Bölümütnde öğrenim gören 3. ve 4. sınıf öğrencileri (toplam 91 kişi) oluşturmaktadır. Katılımcıların cinsiyete göre dağılımı Tablo 1'de gösterilmiştir (Bk. Tablo 1).

Tablo 1. Katılımcıların cinsiyete göre dağılımı

\begin{tabular}{lcc}
\hline Cinsiyet & N & $\%$ \\
\hline Kadın & 55 & 60 \\
\hline Erkek & 36 & 40 \\
\hline Toplam & 91 & 100 \\
\hline Tablo 1'de görüldüğü & gibi öğrencilerin 36'sı (\%40) erkek, 55'i (\%60) kız öğrencidir.
\end{tabular}

Öğrencilerin yaş ortalaması ortalama 20 olarak tespit edilmiştir. 3. ve 4. sınıflardan seçilmelerinin temel sebebi ise 1. ve 2. sınıflara nazaran seçmeli dersler dâhil olmak üzere daha fazla edebiyat dersi almalarından kaynaklanmaktadır.

\section{Verilerin Toplanması ve Analizi}

Çalışmada "Türkçe öğretmeni adaylarının dünya edebiyatını takip etme düzeyleri" problem durumu olarak ele alınmış, ikinci aşamada örneklem grubu belirlenmiş ve tarama modeli için uygun ölçme aracı hazırlanmıştır. Veri toplama aracı olarak "Türkçe Öğretmeni Adaylarının Dünya Edebiyatını Takip Etme Düzeyleri"ni belirlemeye yönelik bir anket hazırlanmış, anket Türkçe Eğitimi ve Edebiyat eğitimi alanlarında iki uzmanın görüşüne sunulmuştur. Gelen dönütlerle birlikte gerekli düzeltmeler yapılmış, ardından ankete son hâli verilmiş ve araştırmaya katılan örneklem grubuna sunulmuştur. Verilerin analiz edilmesinde betimsel analiz kullanılmış olup ulaşılan sonuçlar, bulgular kısmında gösterilmektedir.

\section{Bulgular ve Yorum}

Çalışma kapsamında dünya edebiyatını takip etme ile yabancı dil bilme arasındaki ilişki ortaya konulmaya çalışımış, bu nedenle katılımcılara ilk olarak bildikleri bir yabancı dil olup olmadığı sorusu yöneltilmiştir. Katılımcıların 17'si bir yabancı dil bildiğini belirtirken, 74'ü herhangi bir yabancı dil bilmediğini belirtmişlerdir. Bilinen yabancı diller ise şu şekildedir (Bk. Tablo 2):

Tablo 2. Bilinen Yabancı Diller ve Öğrenci Sayısı

\begin{tabular}{lc}
\hline Bilinen Yabancı Dil & Öğrenci Sayısı \\
\hline İngilizce & 13 \\
\hline Arapça & 1 \\
\hline Flemenkçe & 1 \\
\hline Almanca & 1 \\
\hline
\end{tabular}

\footnotetext{
† 2016-2017 Eğitim-Öğretim Yılı itibarıyla Türkçe ve Sosyal Bilimler Eğitimi Bölümü olarak değişmiştir.
} 


\begin{tabular}{ll}
\hline Farsça & 1 \\
\hline Toplam & 17 \\
\hline
\end{tabular}

Tablo 2'den anlaşıldığı gibi 91 öğrenciden sadece 17'si bir yabancı dil bildiğini belirtmiştir. Toplam öğrenci sayısının \%18'ine karşılık gelen bu sayı genel oran içinde oldukça düşüktür. Bilinen yabancı diller içinde ise İngilizce (13 kişi) ilk sıradadır. Arapça, Flemenkçe, Almanca, Farsça ise sadece birer kişi tarafından bilinmektedir. Öğretmen adaylarının bildikleri yabancı dil ile yazılmış herhangi bir edebî metni okuyup anlayıp anlamadıkları sorulmuş, alınan cevaplar Grafik 1'de gösterilmiştir (Bk. Grafik 1).

Grafik 1. Türkçe Öğretmeni Adaylarının Bildikleri Yabancı Dilde Yazılmış Bir Metni Anlama Düzeyleri

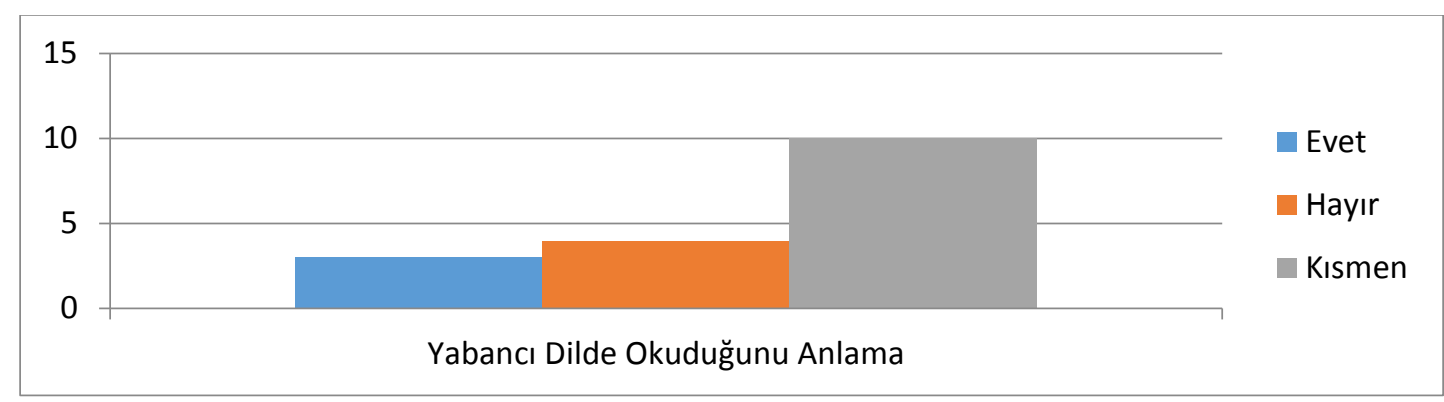

Grafik 1'den anlaşıldığı gibi katılımcıların sadece 3'ü yabancı dille yazılmış bir metni okuyup anlayabildiklerini belirtirken, 4'ü anlayamadıklarını ifade etmiş, 10 öğretmen adayı ise yabancı dille yazılmış metinleri kısmen anlayabildiğini belirtmiştir. O hâlde 91 öğretmen adayının sadece 3'ünün yabancı dille yazılmış metinleri tam olarak anlayabildikleri, buna karşın geri kalan toplam $88^{\prime}$ inin dünya edebiyatını ağırlıklı olarak çevirileri aracılığı ile takip edebildiği ve okuyabildiği sonucuna ulaşılmaktadır.

Katılımcıların yabancı dil bilmemesi kadar, bildiği yabancı dilin dünya edebiyatını takip etmesinde yeterli olmaması da öğrencilerin birçok eseri çevirisinden okumasını gerektirmektedir. Çeviri eserler ise bilindiği gibi birçok önemli sorunu (sadeleştirme, kültür aktarımı, kaynak dilin hedef dile aktarımındaki zorluklar, çeviri uzmanlığı sorunu vb.) da beraberinde getirmektedir.

Katılımcılara dünya edebiyatından en son okudukları eserin hangisi olduğu sorulmuş, 25'i görüş belirtmezken, toplam 66 öğretmen adayının verdiği yanıtlar Tablo 3'te gösterilmiştir (Bk. Tablo 3).

Tablo 3. Türkçe Öğretmeni Adaylarının Dünya Edebiyatından En Son Okudukları Eser

\begin{tabular}{llllllll}
\hline Sıra & Eser Adı & $\begin{array}{l}\text { Öğrenci } \\
\text { Sayısı }\end{array}$ & $\begin{array}{l}\text { Dünya } \\
\text { Edebiyatı }\end{array}$ & Sıra & Eser Adı & $\begin{array}{l}\text { Öğrenci } \\
\text { Sayısı }\end{array}$ & $\begin{array}{l}\text { Dünya } \\
\text { Edebiyatı }\end{array}$ \\
\hline $\mathbf{1}$ & $\begin{array}{l}1984 \\
\text { (G. Orwell) }\end{array}$ & 4 & $\begin{array}{l}\text { Ingiliz } \\
\text { Edebiyatı }\end{array}$ & $\mathbf{2 7}$ & $\begin{array}{l}\text { Mavi Tüy } \\
\text { (R. Bach) }\end{array}$ & 1 & $\begin{array}{l}\text { Amerikan } \\
\text { Edebiyatı }\end{array}$ \\
\hline $\mathbf{2}$ & $\begin{array}{l}\text { Aklından Bir } \\
\text { Sayı Tut } \\
\text { (J. Verdon) }\end{array}$ & 1 & $\begin{array}{l}\text { Amerikan } \\
\text { Edebiyatı }\end{array}$ & $\mathbf{2 8}$ & $\begin{array}{l}\text { Olasılıksı } \\
\text { (A.Fawer) }\end{array}$ & 1 & $\begin{array}{l}\text { Amerikan } \\
\text { Edebiyatı }\end{array}$ \\
\hline $\mathbf{3}$ & Alamut Kalesi & 1 & Slovenya & $\mathbf{2 9}$ & Ölü Canlar & 1 & Rus \\
\hline
\end{tabular}


Türkçe Öğretmeni Adaylarının Dünya Edebiyatını Takip Etme Düzeyleri

\begin{tabular}{|c|c|c|c|c|c|c|c|}
\hline & (V. Bartol) & & Edebiyatı & & (Gogol) & & Edebiyatı \\
\hline 4 & $\begin{array}{l}\text { Aldatmak } \\
\text { (P. Coelho) }\end{array}$ & 1 & $\begin{array}{l}\text { Brezilya } \\
\text { Edebiyatı }\end{array}$ & 30 & $\begin{array}{l}\text { Palto } \\
\text { (Gogol) }\end{array}$ & 1 & $\begin{array}{l}\text { Rus } \\
\text { Edebiyatı }\end{array}$ \\
\hline 5 & $\begin{array}{l}\text { Aşk ve Gurur } \\
\text { (J. Austen) }\end{array}$ & 2 & $\begin{array}{l}\text { İngiliz } \\
\text { Edebiyatı }\end{array}$ & 31 & $\begin{array}{l}\text { Savaş ve Barış } \\
\text { (Lev Tolstoy) }\end{array}$ & 2 & $\begin{array}{l}\text { Rus } \\
\text { Edebiyatı }\end{array}$ \\
\hline 6 & $\begin{array}{l}\text { Aynı Yıldızın } \\
\text { Altında } \\
\text { J.Green) }\end{array}$ & 1 & $\begin{array}{l}\text { Amerikan } \\
\text { Edebiyatı }\end{array}$ & 32 & $\begin{array}{l}\text { Sefiller } \\
\text { (V. Hugo) }\end{array}$ & 1 & $\begin{array}{l}\text { Fransız } \\
\text { Edebiyatı }\end{array}$ \\
\hline 7 & $\begin{array}{l}\text { Beyaz Diş } \\
\text { (J. London) }\end{array}$ & 1 & $\begin{array}{l}\text { Amerikan } \\
\text { Edebiyatı }\end{array}$ & 33 & $\begin{array}{l}\text { Semerkand } \\
\text { (A.Maalouf) }\end{array}$ & 1 & $\begin{array}{l}\text { Lübnan } \\
\text { Edebiyatı }\end{array}$ \\
\hline 8 & $\begin{array}{l}\text { Bin Muhteşem } \\
\text { Güneş } \\
\text { (H. Huseyni) }\end{array}$ & 3 & $\begin{array}{l}\text { Afgan } \\
\text { Edebiyatı }\end{array}$ & 34 & $\begin{array}{l}\text { Simyacı } \\
\text { (P. Coelho) }\end{array}$ & 1 & $\begin{array}{l}\text { Brezilya } \\
\text { Edebiyatı }\end{array}$ \\
\hline 9 & $\begin{array}{l}\text { Bir Dilek Tut } \\
\text { Benim İçin } \\
\text { (M. Binchy) }\end{array}$ & 1 & $\begin{array}{l}\text { İrlanda } \\
\text { Edebiyatı }\end{array}$ & 35 & $\begin{array}{l}\text { Sol Ayağım } \\
\text { (C. Brown) }\end{array}$ & 1 & $\begin{array}{l}\text { İrlanda } \\
\text { Edebiyatı }\end{array}$ \\
\hline 10 & $\begin{array}{l}\text { Bir Yaz Gecesi } \\
\text { Rüyası } \\
\text { (Shakespeare) }\end{array}$ & 1 & $\begin{array}{l}\text { İngiliz } \\
\text { Edebiyatı }\end{array}$ & 36 & $\begin{array}{l}\text { Toprak Ana } \\
\text { (C. Aytmatov) }\end{array}$ & 1 & $\begin{array}{l}\text { Kırgız } \\
\text { Edebiyatı }\end{array}$ \\
\hline 11 & $\begin{array}{l}\text { Bitmeyen } \\
\text { Kavga } \\
\text { (J. Steinbeck) }\end{array}$ & 1 & $\begin{array}{l}\text { Amerikan } \\
\text { Edebiyatı }\end{array}$ & 37 & $\begin{array}{l}\text { Uçurtma Avcısı } \\
\text { (H. Huseyni) }\end{array}$ & 1 & $\begin{array}{l}\text { Afgan } \\
\text { Edebiyatı }\end{array}$ \\
\hline 12 & $\begin{array}{l}\text { Böğürtlen Kışı } \\
\text { (S. Jio) }\end{array}$ & 1 & $\begin{array}{l}\text { Amerikan } \\
\text { Edebiyatı }\end{array}$ & 38 & $\begin{array}{l}\text { Uğultulu } \\
\text { Tepeler } \\
\text { (E. Bronte) }\end{array}$ & 1 & $\begin{array}{l}\text { İngiliz } \\
\text { Edebiyatı }\end{array}$ \\
\hline 13 & $\begin{array}{l}\text { Böyle Buyurdu } \\
\text { Zerdüşt } \\
\text { (Nietzsche) }\end{array}$ & 1 & $\begin{array}{l}\text { Alman } \\
\text { Edebiyatı }\end{array}$ & 39 & $\begin{array}{l}\text { Vadideki } \\
\text { Zambak } \\
\text { (Balzac) } \\
\end{array}$ & 2 & $\begin{array}{l}\text { Fransız } \\
\text { Edebiyatı }\end{array}$ \\
\hline 14 & $\begin{array}{l}\text { Büyük Umutlar } \\
\text { (C. Dickens) }\end{array}$ & 1 & $\begin{array}{l}\text { Ingiliz } \\
\text { Edebiyatı }\end{array}$ & 40 & $\begin{array}{l}\text { Veba } \\
\text { (A.Camus) }\end{array}$ & 1 & $\begin{array}{l}\text { Fransız } \\
\text { Edebiyatı }\end{array}$ \\
\hline 15 & $\begin{array}{l}\text { Cesur Yeni } \\
\text { Dünya } \\
\text { (A.Huxley) }\end{array}$ & 1 & $\begin{array}{l}\text { İngiliz } \\
\text { Edebiyatı }\end{array}$ & 41 & $\begin{array}{l}\text { Vişne Bahçesi } \\
\text { (Çehov) }\end{array}$ & 1 & $\begin{array}{l}\text { Rus } \\
\text { Edebiyatı }\end{array}$ \\
\hline 16 & $\begin{array}{l}\text { Çavdar } \\
\text { Tarlasında } \\
\text { Çocuklar } \\
\text { (J.D. Salinger) }\end{array}$ & 1 & $\begin{array}{l}\text { Amerikan } \\
\text { Edebiyatı }\end{array}$ & 42 & $\begin{array}{l}\text { Yabancı } \\
\text { (A.Camus) }\end{array}$ & 1 & $\begin{array}{l}\text { Fransız } \\
\text { Edebiyatı }\end{array}$ \\
\hline 17 & $\begin{array}{l}\text { Çocukluğum } \\
\text { (M.Gorki) }\end{array}$ & 1 & $\begin{array}{l}\text { Rus } \\
\text { Edebiyatı }\end{array}$ & 43 & $\begin{array}{l}\text { Yeraltından } \\
\text { Notlar } \\
\text { (Dostoyevski) }\end{array}$ & 1 & $\begin{array}{l}\text { Rus } \\
\text { Edebiyatı }\end{array}$ \\
\hline 18 & $\begin{array}{l}\text { Demir Ökçe } \\
\text { (J. London) }\end{array}$ & 1 & $\begin{array}{l}\text { Amerikan } \\
\text { Edebiyatı }\end{array}$ & 44 & $\begin{array}{l}\text { Yeşil Deniz } \\
\text { Kabuğu } \\
\text { (S. Jio) }\end{array}$ & 1 & $\begin{array}{l}\text { Amerikan } \\
\text { Edebiyatı }\end{array}$ \\
\hline 19 & $\begin{array}{l}\text { Derviş ve Ölüm } \\
\text { (M. Selimoviç) }\end{array}$ & 1 & $\begin{array}{l}\text { Yugoslav } \\
\text { Edebiyatı }\end{array}$ & 45 & $\begin{array}{l}\text { Yüzbaşının Kızı } \\
\text { (Puşkin) }\end{array}$ & 1 & $\begin{array}{l}\text { Rus } \\
\text { Edebiyatı }\end{array}$ \\
\hline 20 & $\begin{array}{l}\text { Diriliş } \\
\text { (Lev Tolstoy) }\end{array}$ & 2 & $\begin{array}{l}\text { Rus } \\
\text { Edebiyatı }\end{array}$ & 46 & $\begin{array}{l}\text { Kalp Yalnız } \\
\text { İçeriden Açılan } \\
\text { Bir Kapıdır } \\
\text { (J.P. Sendker) }\end{array}$ & 1 & $\begin{array}{l}\text { Alman } \\
\text { Edebiyatı }\end{array}$ \\
\hline 21 & $\begin{array}{l}\text { Fareler ve } \\
\text { Insanlar } \\
\text { (J. Steinbeck) }\end{array}$ & 1 & $\begin{array}{l}\text { Amerikan } \\
\text { Edebiyatı }\end{array}$ & 47 & $\begin{array}{l}\text { Kavgam } \\
\text { (A.Hitler) }\end{array}$ & 1 & $\begin{array}{l}\text { Alman } \\
\text { Edebiyatı }\end{array}$ \\
\hline 22 & $\begin{array}{l}\text { Faust } \\
\text { (Goethe) }\end{array}$ & 3 & $\begin{array}{l}\text { Alman } \\
\text { Edebiyatı }\end{array}$ & 48 & $\begin{array}{l}\text { Kırmızı } \\
\text { Pazartesi } \\
\text { (G.G. } \\
\text { Marquez) }\end{array}$ & 4 & $\begin{array}{l}\text { Latin } \\
\text { Amerika } \\
\text { Edebiyatı }\end{array}$ \\
\hline
\end{tabular}




\begin{tabular}{|c|c|c|c|c|c|c|c|}
\hline 23 & $\begin{array}{l}\text { Genç Werter'in } \\
\text { Acıları } \\
\text { (Goethe) }\end{array}$ & 1 & $\begin{array}{l}\text { Alman } \\
\text { Edebiyatı }\end{array}$ & 49 & $\begin{array}{l}\text { Küçük Prens } \\
\text { (A.de S. } \\
\text { Exupery) }\end{array}$ & 2 & $\begin{array}{l}\text { Fransız } \\
\text { Edebiyatı }\end{array}$ \\
\hline 24 & $\begin{array}{l}\text { Goodfather } \\
\text { (M. G. Puzo) }\end{array}$ & 1 & $\begin{array}{l}\text { Amerikan } \\
\text { Edebiyatı }\end{array}$ & 50 & $\begin{array}{l}\text { Labirent Son } \\
\text { İsyan } \\
\text { (J. Dashner) }\end{array}$ & 1 & $\begin{array}{l}\text { Amerikan } \\
\text { Edebiyatı }\end{array}$ \\
\hline 25 & $\begin{array}{l}\text { Goriot Baba } \\
\text { (Balzac) }\end{array}$ & 1 & $\begin{array}{l}\text { Fransız } \\
\text { Edebiyatı }\end{array}$ & 51 & $\begin{array}{l}\text { Mart } \\
\text { Menekşeleri } \\
\text { (S. Jio) }\end{array}$ & 1 & $\begin{array}{l}\text { Amerikan } \\
\text { Edebiyatı }\end{array}$ \\
\hline 26 & $\begin{array}{l}\text { Gün Olur Asra } \\
\text { Bedel } \\
\text { (C. Aytmatov) }\end{array}$ & 1 & $\begin{array}{l}\text { Kırgız } \\
\text { Edebiyatı }\end{array}$ & & & & \\
\hline & Toplam & & & & & & \\
\hline
\end{tabular}

Tablo 3'te en son okunan eserler ve bu eserlerin dünya edebiyatındaki yeri gösterilmektedir. Tablodan anlaşıldığı gibi Amerikan Edebiyatından Fransız Edebiyatına, İrlanda Edebiyatından Slovenya Edebiyatına kadar birçok edebiyattan eserler okunmuş olmakla birlikte bunların dağılımlarının eşit ya da birbirine yakın olduğu söylenemez. Bazıları daha fazla tercih edilirken bazı toplumların edebiyatlarının daha az okunduğu görülmektedir. Bunun çok çeşitli sebebi olmakla birlikte genel olarak bilinmeme, ulaşılamama, çevirilerinin henüz yapılmamış olması vb. gibi hususlar bunların başında gelmektedir. Öğretmen adaylarının en çok hangi toplumun edebiyatına ağırlık verdiklerinin daha iyi anlaşılması için Grafik 2'de en son okunan eserlerin dünya edebiyatındaki yerlerine göre tasnifi gösterilmiştir (Bk. Grafik 2).

Grafik 2. Türkçe Öğretmeni Adaylarının En Son Okudukları Eserlerin Dünya Edebiyatındaki Yeri

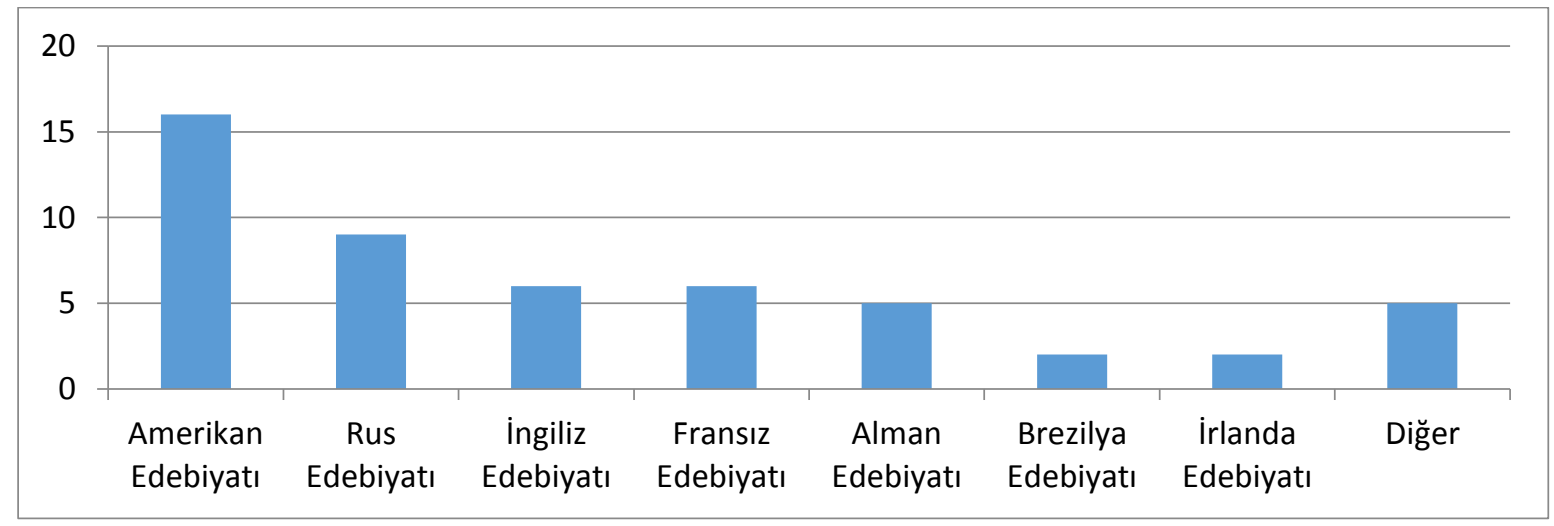

Grafik 2'den anlaşıldığı gibi öğretmen adaylarının en son okudukları eserler arasında Amerikan edebiyatının payı oldukça fazladır. Bunu Rus Edebiyatı, İngiliz Edebiyatı, Fransız Edebiyatı, Alman Edebiyatı, Brezilya ve İrlanda Edebiyatları takip etmektedir. Diğer şeklinde sunulan seçenek ise Slovenya, Lübnan, Yugoslavya, Kırgız ve Latin Amerika Edebiyatlarını kapsamaktadır. Amerikan Edebiyatının okunma oranının yüksek olmasında, birçok eserin aynı zamanda beyazperdeye aktarılmış olması ve kısa zamanda geniş kitlelere yayılması ile birlikte popüler hâle gelmesinin de etkisinin olduğu düşünülebilir. 
Katılımcılara dünya edebiyatından en çok hangi türde yazılmış eserleri okudukları/tercih ettikleri sorulmuş ve alınan cevaplar Tablo 4'te gösterilmiştir (Bk. Tablo 4). Bir öğretmen adayının tek bir türü değil, birden fazla edebî türü de dünya edebiyatından okuyabileceği düşünüldüğünden katılımcılar sınırlandırılmamıştır.

Tablo 4. Türkçe Öğretmeni Adaylarının Dünya Edebiyatından Okudukları/Tercih Ettikleri Türler

\begin{tabular}{ll}
\hline Türler & Öğrenci Sayısı (n) \\
\hline Deneme & 9 \\
\hline Biyografi & 3 \\
\hline Hikâye & 33 \\
\hline Roman & 83 \\
\hline Şiir & 10 \\
\hline Diğer & 0 \\
\hline
\end{tabular}

Tablo 4'teki veriler incelendiğinde dünya edebiyatından en fazla okunan ve tercih edilen türün roman olduğu anlaşılmaktadır. Romanın tercih edilen türlerin başında geldiği ve diğer türlerle arasında büyük fark olduğu görülmektedir. Romandan sonra sırasıyla hikâye, şiir, deneme ve biyografi türünün tercih edildiği tespit edilmiş olup diğer edebî türlere ilişkin bir bulguya ulaşılamamıştır.

Öğretmen adaylarına dünya edebiyatından -sürekli- takip ettikleri bir yazar olup olmadığı sorulmuştur. $21^{\prime} i$ sürekli takip ettiği bir yazar olduğunu belirtirken 70 öğretmen adayı, takip ettiği herhangi bir yazar olmadığını belirtmiştir. Katılımcıların takip ettiklerini söyledikleri yazarlar ise Tablo 5'te gösterilmektedir (Bk. Tablo 5).

Tablo 5. Türkçe Öğretmeni Adaylarının Sürekli Takip Ettikleri Yazarlar

\begin{tabular}{lcl}
\hline Yazar Adı & $\begin{array}{c}\text { Öğrenci } \\
\text { Sayısı }\end{array}$ & Dünya Edebiyatındaki Yeri \\
\hline Adam Fawer & 2 & Amerikan Edebiyatı \\
\hline CengizAytmatov & 2 & Kırgız Edebiyatı \\
\hline Charles Dickens & 1 & Ingiliz Edebiyatı \\
\hline Dan Brown & 1 & Amerikan Edebiyatı \\
\hline Dostoyevski & 2 & Rus Edebiyatı \\
\hline Jean C. Grange & 1 & Fransız Edebiyatı \\
\hline John Steinbeck & 1 & Amerikan Edebiyatı \\
\hline Judith McNaught & 1 & Amerikan Edebiyatı \\
\hline Kristian Hannah & 1 & Amerikan Edebiyatı \\
\hline Khaled Hosseini & 2 & Afgan Edebiyatı \\
\hline Paulo Coelho & 1 & Brezilya Edebiyatı \\
\hline Sarah Jio & 4 & Amerikan Edebiyatı \\
\hline Stephanie Meyer & 1 & Amerikan Edebiyatı \\
\hline Umberto Eco & 1 & Italyan Edebiyatı \\
\hline Toplam & 21 & \\
\hline
\end{tabular}

Tablo 5'e göre 11 kişi Amerikan Edebiyatından bir yazarı, 2 kişi Kırgız Edebiyatından, 2 kişi Rus Edebiyatından, 2 kişi Fransız Edebiyatından, 2 kişi Afgan Edebiyatından, 1'er kişi ise italyan ve Brezilya Edebiyatından bir yazarı takip etmektedir. Ancak bir noktanın belirtilmesi gerekmektedir. Öğretmen adaylarının takip ettiğini söylediği yazarlardan bazıları dünya edebiyatında çok önemli isimler olmakla 
beraber bugün hayatta değillerdir. Bu nedenle takip edilemeyip ancak mevcut eserleri okunabilir. Çalışmanın yapıldığı dönemde takip edilen güncel yazarlar arasında Adam Fawer, Dan Brown, Jean C. Grange, Judith McNaught, Kristian Hannah, Khaled Hosseini, Paulo Coelho, Sarah Jio, Stephanie Meyer, Umberto Eco (ö. 2016) vd. gibi önemli isimler yer almaktadır.

Katılımcıların büyük çoğunluğunun yabancı dil bilmemesi (74 kişi) ve yabancı dil bildiğini belirtenlerin de çok az bir bölümünün ( 3 kişi) yabancı dille okuduğunu anlayabilmesi diğer öğretmen adaylarının (88 kişi) çeviri eserlere yönelmesini zorunlu kılmaktadır. Bu nedenle dünya edebiyatını yakından takip edenler için önemli bir konu ortaya çıkmaktadır: çevirmen sorunu.

Bir eserin çevirmeni eserin yazarı kadar önem taşımaktadır. Suçin, (2007) "Zira çevirmen, kaynak dilden hedef dile bir mesajı aktardığında sadece dilden dile bir aktarımda bulunmamakta, aynı zamanda kültürden kültüre aktarım yapmış olmaktadır. Bununla birlikte dilin anlambilimsel ve kullanımsal yönü de çeviri sürecinde çevirmeni ilgilendirmektedir" (Suçin, 2007:19-20) diyerek çeviri faaliyetlerinde çevirmenin görevinin zorluğuna işaret etmektedir. Kaynak dil ve hedef dil arasındaki geçişin sağlam olması çevirmenin ustalığı ile doğru orantılıdır. Çeviri eserlerde önemli bir diğer husus olan çevirmen hakkında da öğretmen adaylarının görüşlerine ulaşılmak istenmiş, bu nedenle katılımcılara bildikleri edebiyat çevirmeni olup olmadığı sorusu yöneltilmiştir. Katılımcıların 14'ü bildiği bir çevirmen olduğunu belirtirken 77'si herhangi bir edebiyat çevirmeni bilmediklerini ifade etmişlerdir. Alınan cevaplar doğrultusunda tespit edilen edebiyat çevirmenleri Tablo 6'da gösterilmektedir (Bk. Tablo 6).

Tablo 6. Türkçe Öğretmeni Adaylarının Bildikleri Edebiyat Çevirmenleri

\begin{tabular}{ll}
\hline Edebiyat Çevirmenleri & Öğrenci Sayısı \\
\hline Tomris Uyar & 3 \\
\hline Selim Illeri & 1 \\
\hline Hasan Ali Yücel & 5 \\
\hline Sabahattin Ali & 2 \\
\hline Püren Özgören & 1 \\
\hline Orhan Veli & 1 \\
\hline Azra Erhat & 1 \\
\hline Toplam & $\mathbf{1 4}$ \\
\hline
\end{tabular}

Tablo 6'ya göre katılımcılar tarafından yaygın olarak bilenen çevirmenlerin başında Hasan Ali Yücel gelmektedir. Hasan Ali Yücel'i Sabahattin Ali ve Tomris Uyar seçenekleri takip etmektedir. Bilinen diğer çevirmenler ise Selim İleri, Püren Özgören, Orhan Veli ve Azra Erhat'tır. Toplam 14 öğretmen adayından alınan veriler doğrultusunda katılımcıların çevirmen bilme-tanıma-takip etme noktasında zayıf oldukları sonucuna ulaşılabilir.

Dünya edebiyatının en önemli konularından bir tanesi zaman zaman edebî eserlerin okunurluğunu, zaman zaman da yazarın tanınırlığını olumlu şekilde etkileyen ödüllerdir. Bu ödüllerin 
bazen siyasi, bazen kültürel nedenlerle verildiğine rastlansa da okuyucu üzerinde etkili olduğu gerçektir. Bu nedenle katılımcılara dünya edebiyatında bildikleri uluslararası edebiyat ödüllerinin olup olmadığı sorulmuştur. Toplam 66 kişi dünya edebiyatında verilen bir ödül bilmediğini, 25 kişi ise bildiği ödül/ödüller olduğunu belirtmişlerdir. Öğrencilerden alınan yanıtlar Grafik 3’te gösterilmiştir (Bk. Grafik 3).

Grafik 3. Türkçe Öğretmeni Adaylarının Bildikleri Uluslararası Edebiyat Ödülleri

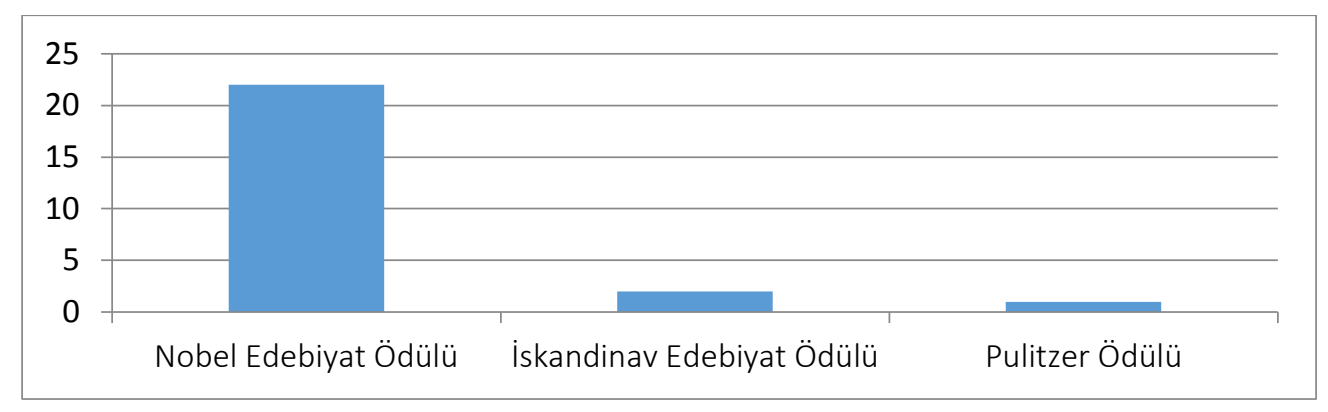

Çalışmaya katılan öğretmen adaylarının dünya edebiyatındaki önemli ödülleri bilme düzeylerinin düşük olduğu Grafik 3'ten anlaşılmaktadır. Yukarıdaki grafiğe göre 22 kişi sadece Nobel edebiyat ödülünü bildiğini belirtirken 2 kişi İskandinav Edebiyat Ödülünü, 1 kişi ise Pulitzer Ödülünü bildiğini belirtmiştir.

Bilindiği gibi Nobel Edebiyat Ödülleri edebiyat alanında verilen ödüllerin başında gelmektedir. İlk olarak 1901 yılında verilmeye başlanan Nobel Edebiyat Ödülleri dünyanın en saygın ödülleri arasında yer almaktadır. Nobel Edebiyat Ödülleri ile ilgili lisansüstü düzeyde çalışma yapan Küçükislamoğlu (2014) “Önemi herkesçe kabul edilse de birçok eleştirmen ve okuyucu Nobel kurumunu eleştirmekte, İsveç Akademisi'nin kararlarını ve gerekçelerini çoğunlukla doğru bulmamaktadır. Akademi her sene ödülü neden ilgili yazara verdiğini açıklasa da bu, çoğunluğu tatmin etmemekte, kararların arkasında genellikle siyasi olmak üzere farklı nedenler aranmaktadır. 102 yıllık bir ödülün yalnızca siyasi nedenlerle verildiği düşüncesi her zaman doğru olmamakla birlikte tamamen yanlış da değildir" (Küçükislamoğlu, 2014: 9) diyerek verilen ödülün siyasi boyutuna da dikkat çeker. Eleştiriler hangi doğrultuda olursa olsun, Nobel Edebiyat Ödülünün uluslararası düzeyde en saygın ödüllerden biri olduğu su götürmez bir gerçektir.

İskandinav Edebiyat ödülleri ise İskandinav Kurulu tarafından İskandinav dillerince yazılıp yayımlanmış eserlere verilmektedir. 1962 yılından itibaren düzenli olarak her yıl verilmektedir. Pulitzer Ödülü ise tıpkı Nobel ve İskandinav Edebiyat ödülleri gibi saygın bir ödül olup edebiyatın yanı sıra gazetecilik, müzik gibi alanlarda da verilmektedir. Illk olarak 1917 yılında verilen ödül, o tarihten günümüze kadar değişik kategorilerdeki eserlere (hikâye, eleştiri, haber vb.) de verilmiştir. 
Çalışmada katılımcıların sadece 25'inin üç farklı ödül (Nobel Edebiyat Ödülü, İskandinav Edebiyat Ödülü ve Pulitzer Ödülü) hakkında fikir sahibi oldukları anlaşılmıştır. Ancak bunların dışında yaygın bilinen ve uluslararası düzeyde saygın diğer edebiyat ödüllerinden bazıları şunlardır: World Fantasy Award, Locus Ödülleri, Goncourt Akademisi Edebiyat Ödülü, Renaudot Ödülü, Man Booker Uluslararası Ödülü, Franz Kafka Ödülü.

Katılımcılara uluslararası edebiyat ödülü alan yabancı yazarlardan bildiklerinin olup olmadığı sorulmuştur. 85 öğretmen adayı Hayır yanıtını verirken, 6 öğretmen adayı ise Evet yanıtını vererek uluslararası edebiyat ödülü almış bir yazar tanıdıklarını belirtmişlerdir. 8 kişinin bildiğini ifade ettiği ödül almış yazarlar Tablo 7'de gösterilmiştir (Bk. Tablo 7).

Tablo 7. Türkçe Öğretmeni Adaylarının Uluslararası Edebiyat Ödülü Alan Yazarlardan Tanıdıkları/Takip Ettikleri

\begin{tabular}{llll}
\hline Yazar & Ödül & Dünya Edebiyatındaki Yeri & $\begin{array}{l}\text { Öğrenci } \\
\text { Sayısı }\end{array}$ \\
\hline Albert Camus & Nobel Edebiyat Ödülü (1957) & Fransız Edebiyatı & 2 \\
\hline H. Bergson & Nobel Edebiyat Ödülü (1927) & Fransız Edebiyatı & 1 \\
\hline G. G. Morques & Nobel Edebiyat Ödülü (1982) & Latin Amerika Edebiyatı & 2 \\
\hline John Steinbeck & Nobel Edebiyat Ödülü (1962) & Amerikan Edebiyatı & 1 \\
\hline & & & Toplam
\end{tabular}

Tablo 7 incelendiğinde öğretmen adaylarının genelinin herhangi bir edebiyat ödülü alan yazar tanımadıkları, sadece altı kişinin Nobel Edebiyat ödülünü almış yazar tanıdığı anlaşılmakla birlikte, bu sayı katılımcılar genelinde oldukça düşüktür. Sonuç olarak Türkçe öğretmen adaylarının uluslararası edebiyat ödüllerini bilme oranı (Bk. Grafik 3) ile uluslararası ödül almış yazarları bilme oranlarının (Bk. Tablo 7) düşük olduğu söylenebilir.

Türkçe eğitimi kapsamında en önemli derslerden bir tanesini çocuk edebiyatı dersi oluşturmaktadır. Bireylere okuma alışkanlığının kazandırılabilmesi onların gelişimlerine uygun kitapların tavsiyesi ve okutturulmasıyla sağlanır. Bu yüzden Türkçe öğretmeni olacak her adayın çocuk edebiyatına vakıf olması, dünya çocuk edebiyatı eserlerinin yanı sıra çocuk edebiyatı alanındaki ödüllü eserleri de takip etmesi gerekir. Araştırmaya katılan öğretmen adaylarına bildikleri uluslararası çocuk edebiyatı ödülü olup olmadığı sorulmuş verilen cevaplar Grafik 4’te gösterilmiştir (Bk. Grafik 4).

Grafik 4. Türkçe Öğretmeni Adaylarının Bildikleri Uluslararası Çocuk Edebiyatı Ödülleri

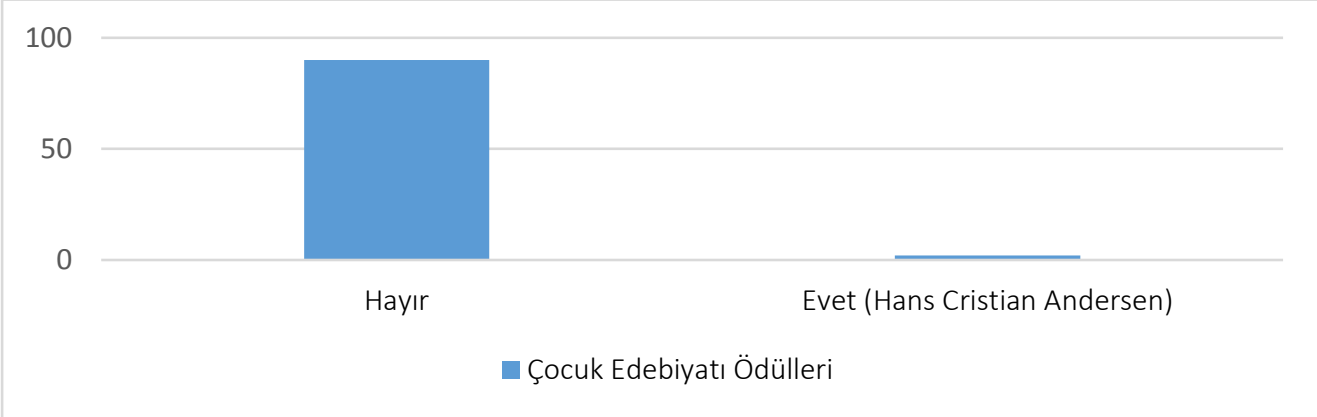


Grafik 4'ten anlaşıldığı gibi katılımcıların tamamına yakınının uluslararası çocuk edebiyatı ödüllerinden herhangi birini bilmedikleri sonucuna ulaşılmaktadır. 89 kişi herhangi bir ödül bilmediğini belirtirken sadece 2 kişi uluslararası çocuk edebiyatı ödüllerinden Hans Cristian Andersen ödülünü bildiğini belirtmiştir. İki kişinin de genel oran içinde çok az olduğu görülmektedir.

Hans Cristian Andersen ödülü, çocuk edebiyatının Nobeli kabul edilmekte olup bu alanda verilen ödüllerin başında gelmektedir. Hans Cristian Andersen ödülünün yanı sıra her yıl İsveç hükümeti tarafından ünlü çocuk ve gençlik edebiyatı yazarı Astrid Lingren'in anısına verilen ALMA (Astrid Lingren Memorial Award) ödülü, uluslararası düzeyde kabul edilen bir diğer önemli ödüldür. Türkçe öğretmeni adaylarının gerek Nobel, Pulitzer, Kafka vb. gibi edebiyat ödüllerini gerekse ALMA, Hans Cristian Andersen vb. gibi çocuk edebiyatı alanındaki önemli ödüller hakkında fikir sahibi olmaları gerekmektedir; çünkü ödül ve ödüllü eser bilme dünya edebiyatını takip etme sürekliliğinin sağlanması açısından önem taşır.

Türkçe öğretmeni adaylarına dünya edebiyatındaki eserleri takip etme yolları sorulmuş, alınan cevaplar Grafik 5’te gösterilmiştir (Bk. Grafik 5).

Grafik 5. Türkçe Öğretmeni Adaylarına Dünya Edebiyatındaki Eserleri Takip Etme Yolları



Grafik 5 incelendiğinde Türkçe öğretmeni adaylarının dünya edebiyatındaki bir eseri en çok kitap aracılığı ile takip ettikleri/okudukları anlaşılmaktadır. Kitap seçeneğini sinema ve tiyatro aracılığı ile takip etme seçenekleri izlemektedir.

Katılımcılara dünya edebiyatından sinemaya aktarıldığını bildikleri eserler olup olmadığı sorulmuş, 50 öğrencinin Evet, 42 öğrencinin ise Hayır yanıtını verdiği görülmüştür. Evet yanıtını veren öğretmen adaylarının, kitaptan sinemaya uyarlanan filmlerden bildikleri, toplanan veriler doğrultusunda, Tablo 8'de gösterilmiştir (Bk. Tablo 8).

Tablo 8. Türkçe Öğretmeni Adaylarının Dünya Edebiyatından Beyazperdeye Aktarıldığını Bildikleri Eser(ler)

\begin{tabular}{|c|c|c|c|}
\hline Eser Adı & Yazar Adı & $\begin{array}{l}\text { Dünya Edebiyatı İçindeki } \\
\text { Yeri }\end{array}$ & $\begin{array}{l}\text { Öğrenci } \\
\text { Sayısı }\end{array}$ \\
\hline Açlık Oyunları & Suzanne Collins & Amerikan Edebiyatı & 6 \\
\hline Akıl Oyunları & Slyvia Nasar & Amerikan Edebiyatı & 2 \\
\hline Alacakaranlık Serisi & Stephenie Meyer & Amerikan Edebiyatı & 5 \\
\hline Anna Karenina & Lev Tolstoy & Rus Edebiyatı & 2 \\
\hline
\end{tabular}




\begin{tabular}{|c|c|c|c|}
\hline Ana & Maksim Gorki & Rus Edebiyatı & 1 \\
\hline Aşk ve Gurur & Jane Austen & İngiliz Edebiyatı & 5 \\
\hline Şeker Portakalı & J. M. de Vasconcelos & Brezilya Edebiyatı & 8 \\
\hline Oliver Twist & Charles Dickens & İngiliz Edebiyatı & 1 \\
\hline Pamuk Prenses & Grimm Kardeşler & Alman Edebiyatı & 3 \\
\hline Beşinci Dalga & Rick Yansey & Amerikan Edebiyatı & 1 \\
\hline Denizler Altında Yirmibin Fersah & Jules Verne & Fransız Edebiyatı & 1 \\
\hline Dünyanın Merkezine Yolculuk & Jules Verne & Fransız Edebiyatı & 1 \\
\hline Fareler ve İnsanlar & John Steinbeck & Amerikan Edebiyatı & 1 \\
\hline Don Kişot & Cervantes & İspanyol Edebiyatı & 2 \\
\hline Gülün Adı & Umberto Eco & İtalyan Edebiyatı & 1 \\
\hline Harry Potter & J.K. Rowling & İngiliz Edebiyatı & 7 \\
\hline Jul Sezar & William Shakespeare & İngiliz Edebiyatı & 1 \\
\hline Labirent & James Dashner & Amerikan Edebiyatı & 1 \\
\hline Madam Bovary & Gustave Flaubert & Fransız Edebiyatı & 1 \\
\hline Monte Cristo Kontu & Alexandre Dumas & Fransız Edebiyatı & 2 \\
\hline Romeo ve Juliet & William Shakespeare & İngiliz Edebiyatı & 2 \\
\hline Sefiller & Victor Hugo & Fransız Edebiyatı & 11 \\
\hline Robin Hood & Howard Pyle & Amerikan Edebiyatı & 1 \\
\hline Robinson Crusoe & Daniel Defoe & İngiliz Edebiyatı & 1 \\
\hline Suç ve Ceza & Dostoyevski & Rus Edebiyatı & 2 \\
\hline Gazap Üzümleri & John Steinbeck & Amerikan Edebiyatı & 1 \\
\hline Uçurtma Avcısı & Halit Hüseyni & Afgan Edebiyatı & 1 \\
\hline Taş Meclis & Jean-Christophe Grangé & Fransız Edebiyatı & 1 \\
\hline Yüzüklerin Efendisi & J. R. R. Tolkien & İngiliz Edebiyatı & 4 \\
\hline
\end{tabular}

Tablo 8 incelendiğinde sinemaya aktarılan birçok edebî eserin öğretmen adayları tarafından takip edildiği ve izlendiği sonucuna ulaşılmaktadır. Katılımcıların birden fazla eseri -sinemaya aktarılmış olanlardan- izleyebilecekleri düşüncesinden hareketle sınırlandırmaya gidilmemiştir. Bu nedenle tek bir eseri değil, filmini izledikleri birden fazla eseri yazdıkları da olmuştur. Bu eserler arasında Monte Cristo Kontu, Sefiller, Robin Hood, Robinson Crusoe, Don Kişot vb. gibi dünya edebiyatı klasikleri arasında sayılan eserler ile Akıl Oyunları, Harry Potter, Açlık Oyunları, Alacakaranlık Serisi vb. gibi günümüz dünya edebiyatının önemli eserleri yer almaktadır.

İzlenen/takip edilen bu eserlerin dünya edebiyatında yeri incelendiğinde 8 eserin Amerikan Edebiyatı, 7 eserin İngiliz Edebiyatı, 6 eserin Fransız Edebiyatı, 3 eserin ise Rus edebiyatından olduğu görülecektir. Bunun dışında İtalyan, İspanyol, Brezilya, Afgan ve Alman Edebiyatı kapsamında 1'er eser de bulunmaktadır. Amerikan edebiyatı ile İngiliz Edebiyatından beyazperdeye aktarılan eserlerin sayısının fazla olması bu eserlerin konusu ile de ilgilidir. Son yıllarda Amerikan ve İngiliz edebiyatındaki eserlerin -özellikle fantastik türde olanların- (örneğin Alacakaranlık Serisi, Yüzüklerin Efendisi vd.) sinemaya aktarılmasıyla birlikte geniş bir kitleye hitap ettiği görülmektedir. Bu nedenle Amerikan ve İngiliz edebiyatının takip edilme düzeyi de buna bağı̆ olarak fazladır. Bu görüş Grafik 2'deki veriler ile örtüşmektedir (Bk. Grafik 2). 
Türkçe öğretmeni adaylarının dünya edebiyatını bilmesi ve takip etmesi hem mesleki gelişim hem de kişisel gelişim için gereklidir. Eğitim Fakülteleri Lisans Programları yönetmeliğinde Türkçe Öğretmenliği için hazırlanan lisans programında yer alan derslerden bir tanesi Dünya Edebiyatı dersidir. Ders içeriği; "Dünya edebiyatından Türkçeye özenle çevrilmiş ve dünya edebiyatında tanınmış kitapların okunması ve çözümlenmesi. Dünya klasiklerinden yapılacak bir seçkinin, ezberci ve geleneksel özetleme, karakter tahlili ve betimleme anlayışına kaymadan, çağdaş edebiyat çözümleme anlayışları doğrultusunda incelenmesi. "Okuma Eğitimi" dersinde kazanılan ipuçlarını kullanarak eleştirel okuma uygulamaları" (http://www.yok.gov.tr/) şeklinde yer almış olup Okuma eğitimi ile ilişkilendirilmiştir. Buradan hareketle Dünya edebiyatını bilmenin diğer alan bilgisi dersleri ile ilişkili olduğu, disiplinlerarası çalışmalar neticesinde dünya edebiyatından yararlanılması gerektiği ve çağdaş tahlil metotları kullanılarak eser analiz etme ve değerlendirme becerilerinin kazandırılmasının amaçlandığı sonucuna ulaşılmaktadır. Bu nedenle Türkçe öğretmeni adayları için dünya edebiyatını bilmek ve takip etmek gereklilik olarak görülmelidir.

Katılımcılara "Türkçe öğretmeni adayı olarak dünya edebiyatını takip etmenin önemli olduğunu düşünüyor musunuz?" sorusu yöneltilmiş, 80 kişi önemli olduğunu belirtirken 4 kişi bunun gerekli olmadığını ifade etmiştir. 7 öğrenci ise herhangi bir görüş belirtmemiştir. Evet yanıtını vererek dünya edebiyatını takip etmenin önemli olduğu görüşünde birleşenlerin gerekçeleri de Tablo 9'da gösterilmiştir (Bk. Tablo 9).

Tablo 9. Türkçe Öğretmeni Adaylarına Göre Dünya Edebiyatını Takip Etme Gerekçeleri

\begin{tabular}{lll}
\hline Sıra & Gerekçe & Öğrenci Sayısı \\
\hline 1 & Farklı bakış açısı kazandırır. & 22 \\
\hline 2 & Farklı kültürler, coğrafyalar hakkında fikir edinilir. & 15 \\
\hline 3 & Öğretmen kendini geliştirir. & 12 \\
\hline 4 & Edebiyat evrenseldir. & 7 \\
\hline 5 & Bilgi birikimini artırır. & 6 \\
\hline 6 & Kişinin edebî zevki gelişir. & 6 \\
\hline 7 & Kültürlerarası karşılaştırma yapma olanağı̆ sağlar. & 5 \\
\hline 8 & Yeni anlayım biçimi ve üslup öğrenilebilir. & 4 \\
\hline 9 & ilham kaynağı olabilir. & 1 \\
\hline 10 & Insanlara ders verir. & 1 \\
\hline 11 & Okuma kültürünü geliştirir. & 1 \\
\hline & & Toplam $\mathbf{8 0}$
\end{tabular}

Tablo 9'a göre öğretmen adaylarının dünya edebiyatını takip etme gerekçelerinin farklılık gösterdiği anlaşılmaktadır. Bu gerekçeler arasında ilk sırayı "Farkıı bakış açısı kazandırır (22 kişi)" seçeneği almaktadır. Diğer gerekçeler bir bütün olarak değerlendirildiğinde ise ya kişisel gelişime ya da mesleki gelişime yönelik olduğu görülmektedir. Katılımcıların büyük bir bölümünün dünya edebiyatını takip etmenin gerekli olduğu konusunda hemfikir oldukları sonucuna ulaşıımıştır. Dünya edebiyatını takip etmenin gerekli olmadığını savunan 4 öğrenci ise düşüncelerini, "Önce kendi 
edebiyatımızı öğrenmeliyiz. Kendi edebiyatımız tüm yönleriyle benimsetilip ardından dünya edebiyatına geçilmelidir." şeklinde savunmuşlardır.

\section{Tartışma, Sonuç ve Öneriler}

Türkçe öğretmeni adaylarının dünya edebiyatını takip etme düzeylerini belirlemeye yönelik yapılan bu araştırmada, bulgular doğrultusunda farklı sonuçlara ulaşılmıştır. Katılımcıların genel itibarıyla yabancı dil bilmedikleri (ortalama \%82), dünya edebiyatını çeviri eserler aracılığı ile takip ettikleri/okudukları tespit edilmiştir. Yabancı dil bildiğini ifade eden katılımcıların ise eserleri özgün dillerinde okuyup anlama hususunda yetersiz oldukları tespit edilmiştir (Grafik 1).

Öğretmen adaylarının dünya edebiyatından en son okudukları eserler arasında (Bk. Grafik 2) Amerikan edebiyatının ilk sıralarda yer aldığı, sürekli takip edilen güncel yazarlar (Bk. Tablo 5) arasında Amerikan edebiyatının yine ilk sıralarda olduğu görülmüştür. Edebiyat çevirmeni bilme/tanıma/takip etme (Bk. Tablo 6) ile uluslararası edebiyat ödülü (Bk. Grafik 3) ve uluslararası ödüllü yazar (Bk. Tablo 7) bilme noktasında katııımcıların zayıf oldukları sonucuna ulaşılmıştır. Türkçe öğretmeni adaylarından benzer şekilde uluslararası çocuk edebiyatı ödülü bilme (Bk. Grafik 4) hususunda da yeterli veri elde edilememiştir.

Çoğunlukla roman türünü tercih ettikleri anlaşılan katılımcıların (Bk. Tablo 4), dünya edebiyatından eserleri ağırlıklı olarak kitap aracılığı ile takip ettikleri/okudukları, bu sonucu sırasıyla sinema ve tiyatro aracılığı (Bk. Grafik 5) ile takip etmenin aldığı anlaşılmıştır. Dünya edebiyatından beyazperdeye aktarılan eserler (Bk. Tablo 8) hakkında katılımcıların fikir sahibi oldukları anlaşımakta olup en fazla Amerikan ve İngiliz edebiyatından aktarılan eserlerin izlendiği/takip edildiği sonucuna ulaşılmıştır. Bu sonuçlarda son yıllarda dünya çapında geniş okur kitlesine ulaşan ve daha sonra beyazperde ile yüzbinlerce izleyici kitlesine hitap eden fantastik eserlerin de katkısının olduğu düşünülebilir.

Türkçe öğretmeni adaylarının dünya edebiyatını takip edip etmemeyi gerekli bulup bulmadıkları sorulduğunda genel itibarıyla öğrencilerin dünya edebiyatını takip etmenin gerekli olduğu hususunda hemfikir oldukları tespit edilmiştir. Ağırlıklı olarak farklı bakış açısı kazandırma noktasında dünya edebiyatının gerekli olduğunu savunanlar ile mesleki ve kişisel gelişime katkı sunması açısından gerekli görenlerin olduğu anlaşılmıştır (Bk. Tablo 9).

Sonuç olarak dil öğretiminde metin kullanımının öneminden hareketle Türkçe öğretmeni adaylarının dünya edebiyatına daha fazla eğilmelerinin gerekli olduğu ifade edilebilir. Bunun için lisans düzeyindeki dersler ile ders kitaplarında dünya edebiyatının seçkin örneklerine yer verilerek bakış açısı kazandırılmalı, farkı kültürler tanıtılmalıdır. Gerek klasik edebiyattan gerekse modern edebiyattan eserler okunmalı/okutulmalı ve bu eserler, özellikle lisans programlarında sadece Dünya 
edebiyatı dersi kapsamında ele alınmamalı, diğer dersler içinde de -disiplinlerarasılık bağlamındakaynak olarak kullanılabilmelidir. Dünya edebiyatı derslerinde ise ders süreci, klasik edebiyatın güdümünden çıkarılıp güncel edebiyatlarla da bütünleştirilmeli, farklı toplumların edebiyatlarına yer verilecek şekilde ders içerikleri yeniden düzenlenmelidir.

\section{Kaynaklar}

Avcı, Ş. (2011). "Türkçe ders kitaplarındaki dünya edebiyatı metinlerinin içerik açısından incelenmesi". Yayımlanmamış Yüksek Lisans Tezi. Mustafa Kemal Üniversitesi. Hatay.

Baytekin, B. (2006). Kuramsal ve Uygulamalı Karşılaştırmalı Edebiyat Bilim. Sakarya: Sakarya Yayıncılık.

Busbecq, O. G. De (2004). Türkiye'yi Böyle Gördüm. (Çev. M. Fatih Topaloğlu). İstanbul: Elip Kitap.

Çalışkan, A. (2016). "illköğretim 100 temel eser içerisinde yer alan dünya edebiyatına ait eserlerin değerler eğitimi açısından incelenmesi". Yayımlanmamış Yüksek Lisans Tezi. Selçuk Üniversitesi. Konya.

Damrosch, D. (2013). Dünya Edebiyatı Nedir? İstanbul: İstanbul Bilgi Üniversitesi Yayınları.

Damrosch, D. (2016). Dünya Edebiyatı Nasıl Okunmalı? İstanbul: İstanbul Bilgi Üniversitesi Yayınları.

Gürbilek, N. (2004). Kör Ayna Kayıp Şark Edebiyat ve Endişe. İstanbul: MetisYayınları.

Kolcu, A. i. (2015). Edebiyat Kuramları. Erzurum: Salkımsöğüt Yayınları.

Küçükislamoğlu, Ü. (2014). "Nobel edebiyat ödülünün yapısı ve dünya edebiyatındaki işlevi.” Yayımlanmamış Yüksek Lisans Tezi. İstanbul Bilgi Üniversitesi. İstanbul.

Suçin, M. H. (2007). Çeviribilim Öteki Dilde Var Olmak. İstanbul: Multilingual Yayınları.

Tekşan, M. (2011). Karşılaştırmalı Edebiyat Bilimi. İstanbul: Kriter Yayıncılık.

Tournefort, J. De (2013). Tournefort Seyahatnamesi. (Çev. Teoman Tunçdoğan; Ali Berktay). İstanbul: Kitap Yayınevi.

Uysal, B. (2016). The Evaluation of World Literature Courses in Turkish Language Teaching Departments Based on Conceptual Field. Journal of Education and Training Studies, V. 4, No. 10; ss. 139-147.

Ülken, H. Z. (2011). Uyanış Devirlerinde Tercümenin Rolü. İstanbul: İ̧̧ Bankası Kültür Yayınları.

Yalçın, A. (2012). Çağdaş Edebiyat ve insan. Ankara: Akçağ Yayınları.

2017 Türkçe Dersi Öğretim Programı (ilkokul ve Ortaokul 1, 2, 3, 4, 5, 6, 7 ve 8. Sınıflar), Ankara, 25.03.2017'de http://ttkb.meb.gov.tr/www/ogretim-programlari/icerik/72 adresinden alınmıştır.

http://www.yok.gov.tr/documents/10279/49665/turkce_ogretmenligi.pdf/d0d11c2d-bc83-4186-8717b33597eb8eb6 adresinden 09.03.2016'de alınmıştır. 